\title{
China's Role in Burma's Development
}

\section{Neil Renwick}

Abstract China has been a long-standing partner for Burma (Myanmar), providing important political, military and economic support. Burma's reform process poses new questions and challenges for China. China's interests in Burma are primarily economic-driven by its need for strategic resources and are highly controversial. This study argues that China's approach to Burma's development is determined by its own national economic interests. Beijing's view is that this is a 'win-win' situation. This is a view under critical review in Burma as it seeks to re-balance its foreign relationships. This article details the critical point at which Sino-Burmese relations now stand, explains Burma's current development profile, outlines Chinese involvement in Burma and explains China's development approach to Burma in terms of China's national economic, political and security interests.

\section{中国在缅甸发展中的作用 \\ 尼尔・伦维克}

\begin{abstract}
中国是缅甸的长期合作伙伴，在政治、军事和经济方面为缅甸提供重要的支持。缅 甸的改革进程对中国提出新的问题和挑战。中国在缅甸的利益主要是经济方面的, 由战略资源的需求所驱动并饱受争议。本文认为, 中国对缅甸发展的参与方式是由 其自身的经济利益决定的。中国认为这是 “双赢” 的局面; 缅甸则谨慎审视这一 观点, 力求重新平衡其对外关系。本文详细分析中缅关系的重要立足点, 给出缅 甸现阶段的发展概况及中国的参与情况，从中国国家经济、政治和安全的利益出发 分析了中国参与缅甸发展的方针策略。
\end{abstract}




\section{Introduction}

Burma's post-2011 reforms have excited worldwide interest; attracted by the prospect of new political, economic and strategic opportunities. Although there have been testing times in the relationship, the lowest ebb being in the late 1960s, from the late 1980s China has been a long-standing partner of Burma through the years of military rule and international ostracism. During the decades of Burma's international isolation, China provided important diplomatic support at the United Nations and in the Asia-Pacific region, substantial military armaments, vital investment and infrastructural capacity-building assistance and a market for Burmese goods. For its part, China gained access to Burma's rich endowment of raw materials, energy resources and strategic access to the Indian Ocean.

However, Sino-Burmese relations are now at a crossroads. Burma's unfolding political landscape poses new questions and challenges for the

Beijing leadership and its core national interests in its neighbour. China's political and strategic interests in Burma are important and cannot be discounted easily. But the reality is that Beijing's interests in Burma are primarily economicdriven by its need for strategic resources. This may change as China's specific engagement with international 'development' norms and practices evolves. Currently, though, Burma's

'development', as a Chinese national interest and as a foreign policy objective in its own right, is not central to China's approach. Development is salient insofar as any new spur to regional economic growth offers new economic opportunities and a potential magnifier effect.

But this is a spin-off, a beneficial consequence of the pursuit of Chinese trade and foreign direct investment (FDI) intended to meet China's economic imperatives and reified through Chinese state-owned enterprise (SOE) operations. In the Chinese view, China's trade and FDI are not critical to Burmese development and are not inimical to it - quite the opposite. By trading and investing with Burma and by actively contributing to its infrastructural capacity building, China is also contributing substantively to Burma's 'development'. Indeed, from Burma's standpoint, this infrastructural capacity building is an imperative to achieve economic development. From an Asian perspective, this is also advantageous insofar as it comes with little or no 'strings attached'; no weighty requirements for human rights, democratisation or marketoriented reforms in return for economic relations or aid donor largesse.

China shares a $2,200 \mathrm{~km}$ border with northern and eastern Burma. Building upon the historical circulation of goods, people and cultural influences, fraternal ties gained additional complexity during their respective periods of colonial and semi-colonial subjugation and nationalist and anti-colonial contests.

China's own economic reforms have taken 860 million Chinese citizens out of poverty and, despite its own continuing problems with widening inequality, has an experience and development story that ought to inform its understanding of its Burmese partner's development needs and China's potential contribution.

Yet, as in Africa, Latin America and parts of Southeast Asia, China's operations in Burma are controversial. There have been public protests against large-scale, high-profile mining, hydroelectric, forestry, mining, and energy projects involving Chinese SOEs; issues range from 'land-grabs', to lost employment and environmental degradation, and loss of livelihoods and food supplies. The Thein Sein leadership responded to this discontent in September 2012 by suspending work on the Letpadaung copper mine until 2015.

The following analysis examines issues surrounding China's presence in Burma. The article is structured in four parts. Following this introduction setting out the historic juncture at which Sino-Burmese relations now stand, the article explains Burma's current development profile; the political and economic gains arising from the post-2011 reform process, the continuing challenges it is actively and robustly seeking to confront and overcome, and the new national development framework and plan. It reviews Burma's overall trade, FDI and development assistance indicators as the principal means of achieving the government's development aims. The article then turns its attention to China's approach to Burma and outlines current Chinese engagement in the country and explains China's development approach to Burma in terms of China's national economic, political and security interests. The final part provides concluding comments. 


\section{Burma in development}

Once one of Southeast Asia's economic jewels, years of military rule and international pariah status has distorted Burma's economic development. Burma is the largest territory on mainland Southeast Asia, and second largest in the region as a whole, after Indonesia. It shares borders with five neighbouring states, including India and China. The watchword for Burma today is 'potential' - human, economic and political. Economically, Burma's trade and inward investment are growing as domestic regulatory, legal, financial, corporate and administrative reforms take hold and the international community steadily dismantles its sanctions regimes against Burma. Politically, democratic reforms, elections and a commitment to 'good governance', the release of political prisoners and addressing of human rights abuses, an opening up of the space for civil society organisations and community groups and peace agreements with ethnic military groups have already transformed the landscape in quick time (Amnesty International 2013). Following political reforms and Burma's agreement with international donors on development assistance governance, assistance has flooded in (IndexMundi 2012) from European, Asia-Pacific and North American states and from Japan as well as international organisations such as the EU, World Bank, the International Monetary Fund (IMF) and the Asian Development Bank (ADB), targeting a broad spectrum of development needs from infrastructure, health, education, policing, community enterprise, governance and administration to sovereign debt.

Burma is also resource-rich in its human and material assets. It has a population of over 61 million with an annual population growth rate of 1.1 per cent (ADB 2013), significant improvements in sanitation and water and in health with successful HIV/AIDS and TB programmes and morbidity and mortality rates for malaria already cut by half over the past seven years (UNDP 2013b) and an adult literacy rate of 92.3 per cent. Rangoon and Mandalay are cities with sizeable, and largely younger, populations of five and one million respectively, a ready workforce. Releasing this human potential is a vital necessity for Burma's future development. This is, in turn, linked to the exploitation of the country's resources for economic sustainable growth - arable land, forestry, minerals, natural gas, freshwater and marine resources; Burma is also a leading source of gemstone and jade.

Exports of Burmese jade are booming, so much so that it is now a source of growing concern.

Clearly, economic growth is the principal driver for Burma's development, albeit not the only one. Since taking office in 2010, the civilian government has initiated a wide-ranging programme of economic and financial reforms to shift the country to an open market economy. These have included currency floatation, new fiscal regulations to rationalise personal income tax and reduce consumption tax, telecommunications sector liberalisation, private sector reforms and attracting FDI, a review of the financial sector, promotion of access to finance, and creating an economic climate conducive to job creation. According to World Bank data, the country's economy grew at 7.3 per cent in 2012/13. The main engines of growth were raised gas production, the services and construction sectors, FDI and strong commodity exports. The World Bank estimates that the economy will grow at 7.5 per cent in 2013/14 and increasing to 7.8 per cent in the medium term based on a continuing rise in gas production, increased trade and improved performance in agriculture. Burma's GDP is estimated to have been US $\$ 55$ billion in 2012/13 (World Bank 2014). Burma's total foreign trade in 2012 was US $\$ 13.3$ billion, contributing to about 27 per cent of its GDP.

The country's ability to achieve its development aims depends not only on economic growth but also on processes of democratisation and enhanced governance practices. The dismantling of military rule has seen national elections in 2010 and by-elections in April 2012 with further by-elections due in late 2014 and national elections in November 2014. The civilian government has initiated reforms including parliamentary representation and rules, corruption and transparency, civil society participation, political prisoners and human rights. The task of political development reforms is, like the economic and societal challenges, simply immense and the challenge of overcoming entrenched practices and interests sizeable. For example, entwined political and economic corruption, reified into Burma's governmental and business structures and systems during military rule (Taylor 2001), will be hard to 
Table 1 Burma: Ethnic groups and religions

\begin{tabular}{|c|c|c|c|}
\hline Ethnic groups (\%) & & Religions (\%) & \\
\hline Burman & 68 & \multirow[t]{2}{*}{ Buddhist } & \multirow[t]{2}{*}{89} \\
\hline Shan & 9 & & \\
\hline Kayin (Karen) & 7 & \multirow[t]{2}{*}{ Christian } & \multirow[t]{2}{*}{4} \\
\hline Rakhine (Arakanese) & 4 & & \\
\hline Chinese & 3 & \multirow[t]{2}{*}{ Muslim } & \multirow[t]{2}{*}{4} \\
\hline Mon & 2 & & \\
\hline Indian & 2 & Animist & 1 \\
\hline Miscellaneous & 5 & Miscellaneous & 2 \\
\hline
\end{tabular}

Source Network Myanmar; http://networkmyanmar.org/ images/stories/PDF/stats2009.pdf.

eradicate (Asia Tribune 2012). Indicative of the scale of the task is Burma's low ranking in the Corruption Perceptions Index (CPI) for 2012 by

Transparency International (TI). Burma occupied 172nd place out of 176 countries reviewed (TI 2012).

Attaining the development aims also requires societal stability and peace. The government has moved quickly to try and resolve the country's long-standing ethnic conflicts, although many challenges remain. The government has reached preliminary peace accords with all 11 of the main armed ethnic groups, following preliminary agreement with the Kachin Independence Organisation (KIO) on 30 May 2013 (Australian Government 2014).

Nevertheless, despite this, Burma's development challenge is substantial. For example, Burma's agricultural sector is weakened, pushing growing numbers of unskilled workers into the labour force where low remuneration and job seasonality causes many of these workers to migrate internally or abroad. According to the Swiss Agency for Development and Cooperation (SDG), over 10 per cent of the total population are estimated to be working abroad. Participation in the national labour force is 50 per cent of women compared to 83 per cent of men, and 4.6 per cent of women are unemployed as opposed to 3.7 per cent of men. 'Unequal access to jobs and resources, compounded by the growing income gap, remain challenges to peaceful development' (SDC 2013: 9).
The United Nations Development Programme (UNDP) classifies Burma in the low human development category. Burma's Human Development Index (HDI) value was 0.498, ranking it 149 out of 187 countries and territories for 2012. Between 1980 and 2012, Burma's HDI value rose from 0.281 to 0.498 , an increase of 77 per cent or average annual increase of about 1.8 per cent (UNDP 2013b: 2). Burma had an estimated GDP per capita of US\$868 in 2012/13 (World Bank 2014); over one-quarter of the Burmese population live below the national poverty line, there is an under-five mortality rate of 62 per 1,000 live births (ADB 2013), 32 per cent of children under five suffer from malnutrition (World Bank 2014), and only around half of the children enrolled in primary school actually complete it (MPED 2011). Human Rights Watch reports that, despite the new Burmese government's commitments to the UN Security Council to tackle the issue and become a model of behaviour, 'the longstanding trade in, and systematic abuse of, child soldiers' in Burma persists in the face of Burmese military obduracy (Becker 2013). Burma is ethnically highly diverse. The government recognises 135 separate ethnic groups. The main groups include Burman/Bamar, Shan, Karen/Kayin, Kachin, Chin, Rakhine, Mon and Karenni/Kayah.

This is a culturally rich facet of Burmese society. However, it is also a source of tension, division, violent abuse and conflict; generating societal instability, dislocation and disharmony in parts of Burma. Burma carries the scars of the interethnic conflicts with human rights abuses and the loss of life, livelihoods and homes. It is estimated that such conflict has led to millions of persons being displaced over recent decades. Currently, there are around 140,000 refugees in Thailand and about 200,000 internally displaced persons (IDPs) live in the southeast of the country. An additional 300,000 have been displaced recently due to renewed armed conflict in Kachin State and civil unrest in Rakhine State (SDC 2013: 10).

While the overall demographic distribution is one in which the population density is low spread out across the country with around 70 per cent of the population living in rural areas, the remainder are found in the cities of Yangon [Rangoon] (five million), Mandalay (1.3 million) and Mawlamyine [Moulmein] $(600,000)$. This is 
problematic given that transport links are poor and highly vulnerable to intense climatic events (virtually half of all roads are made impassable during the monsoon season) and telecommunications and internet capacity is extremely limited. Only about one-quarter of Burmese have access to electricity. Rural poverty is double that found in urban centres and particularly high among the largely minority ethnic populations of Burma's border provinces and those regions emerging from conflict.

\subsection{Burma's development aims}

Burma's development path is set within the overall objectives of the reform process. There are four primary reform objectives: (1) balanced and proportionate growth among all states and divisions; (2) prioritisation of food security and amelioration of the agricultural sector;

(3) development that is all-inclusive; and

(4) ensuring the reliability of statistics and an overall improvement in primary data collection (Asia Tribune 2012). In May 2012, President

Thein Sein set out the country's approach to national development (Thin 2013). He identified the reform mechanisms by which Burma would achieve economic development by attracting international ODA and FDI and the administrative framework for managing and disbursing such funds as they are received. The goal is to triple GDP per capita in five years to US $\$ 3,900$. To attract ODA, political reforms, the April 2012 elections and release of some political prisoners led to the easing of international sanctions. To draw in FDI, monetary and currency reforms were followed by a new Foreign Investment Law.

The government's aims are embodied in the Framework for Economic and Social Reforms (FESR) presented at Burma's first Development Cooperation Forum in January 2013 and the National Comprehensive Development Plan (NCDP).

These emphasise the importance of cutting poverty through infrastructural, agricultural and social development, "including the creation of "good governance and clean government", private sector-led growth, and the use of participatory approaches' (SDC 2013: 11). But the consultation and policy formulation process was criticised by some aid organisations for being based on a series of working groups drawn in large part from economic institutes in the Association of Southeast Asian Nations (ASEAN) and Japan with limited civil societal participation (Oxfam 2014). A second Forum was held in late January 2014, under the theme of 'Accelerating Actions for Progress through Enhancing Inclusive Coordination'; participants included the government of Burma, members of parliament, international development partners, and representatives of civil society, the private sector and academia. The government made three commitments: (1) Finalise the Nay Pyi Taw Accord Action Plan to ensure the continued implementation of the Accord; (2) Ensure continued support for the FESR and the NCDP; (3) Strengthen government capacity to lead development efforts and engage with public and private actors in the planning and implementation processes. A third Forum is scheduled for January 2015.

The strategy for achieving these development aims is to promote the inter-connected drivers of growth: trade, FDI and aid. Taking a quick look at these, starting with trade, we have already noted above Burma's encouraging economic growth. Despite returning a trade deficit for the first nine months of 2013, Burma recorded a trade surplus of US $\$ 406.6$ million in December of 2013. From 2010 until 2013, Burma's balance of trade averaged US $\$ 3.83$ million, peaking in August 2011 at US $\$ 593.3$ million and a deficit of US\$639.8 million in June 2011. International marginalisation meant that the years of military rule saw Burma trading primarily with its immediate neighbours out of necessity and expediency, albeit across turbulent borders. Exports consist mainly of oil and natural gas with the remainder accounted for by vegetables, wood, fish, clothing, rubber and fruits. In terms of its imports, these are made up of fuel, vegetable oil, vehicles, pharmaceutical products, construction equipment, polymers, tyres and machinery. Burma's main trading partners are China, India, Japan, Indonesia, Germany and Hong Kong (Trading Economics 2014: 1).

Inward investment is also on the rise following reforms on land and corporate ownership laws and financial services. According to the Burmese investment commission (DICA), inward FDI increased to US $\$ 2.7$ billion in 2012-13, up from US $\$ 1.9$ billion in 2011-12. DICA also estimated that some US\$54 million of FDI had flowed to 
Burma in September 2013 alone, targeted at the manufacturing, agriculture, mining, and hotels and tourism sectors (consult-myanmar.com 2014b). According to some estimates, FDI was likely to almost nearly triple year-on-year in 2013; FDI for April-December alone amounted to roughly US $\$ 2.15$ billion, a 50 per cent increase over total FDI for the whole of 2012 (Nikkei Asian Review 2014).

With respect to development assistance, clearly there is a new international engagement with Burma. Foreign aid providers from the USA, EU, UK, Japan, Australia and many others have moved en masse to offer ODA and to encourage their businesses and public agencies to embed themselves in Burma through FDI. In February 2012, the EU announced a foreign aid package to Burma worth $€ 150$ million, adding to an existing commitment of $€ 50$ million and opened an EU Office in Yangon in April that year, to assist health, education, livelihoods, government capacity building and democratisation processes, inclusive development, aid to uprooted peoples and civil society. The Asian Development Bank has granted US $\$ 512$ million (£325 million), while the World Bank approved a US\$440 million credit line, the loans only being agreed after Burma cleared overdue arrears to the two organisations with Japan's assistance (BBC News 2013). The USA re-established the USAID Mission in 2012. In November 2012, President Obama travelled to Burma, pledging US\$170 million in assistance over two years (US Government 2013).

Australia's contribution to Burma in 2012/13 was A $\$ 64.2$ million with a proposed 2013/14 expenditure of $\mathrm{A} \$ 78.8$ million; Canberra having invested $\mathrm{A} \$ 140.9$ million over the previous three years. The UNDP's 2013-15 programme, developed with the Burmese government, "aims to help Myanmar manage a "triple transition": nation-building; state-building; and economic liberalisation, moving the country from a closed, command economy to an open and transparent market' (UNDP 2013a). A central issue raised by aid donors at the Development Forum was with regard to the effectiveness of all this development assistance. The Burmese government signed the Nay Pyi Taw Accord for Effective Development Cooperation setting out how the government will ensure that development cooperation is transparent and accountable, democratic, and targeted towards reducing poverty and inequality. Further statements have followed committing the government to establishing a robust monitoring of the disbursements of development assistance funding and operations.

\section{China-Burma relations}

\subsection{Economic cooperation}

China is Burma's principal trade and investment partner accounting for a third of Burma's trade annual trade between the two countries is now worth around US $\$ 3.6$ billion. China exports raw materials and equipment to Burma. These are destined for the Chinese investment projects in the country. To date, China is the largest single investor, accounting for almost US\$16 billion. Until the recent agreements to fund energy and large infrastructure projects, much of China's corporate involvement was based on small- and medium-sized firms coming across the border from Yunnan Province. But the recent expansion in Chinese engagement has been driven by China's SOEs in the energy, minerals and construction sectors. Burma is an important economic interest for Beijing with large stakes in the mining, oil and gas sectors with telecommunications next on the agenda. Estimates vary, but the value of Chinese exports is in the region of US $\$ 2$ billion ( $¥ 13$ billion). For its part, Burma exports minerals and agricultural products to China, worth around US $\$ 1.6$ billion.

Chinese firms already have a firm foothold in Burma. Over the period 1988-2013, these firms accounted for almost 33 per cent of the total US $\$ 44$ billion invested during these years. According to recent assessments, the combined amount of FDI from the Chinese mainland and Hong Kong - the first and third largest foreign investors to the country - totalled over US $\$ 20$ billion in Burma in 2012, accounting for nearly half of Burma's total FDI that year (China Daily 2013b). The range of activities is surprisingly diverse - from cement to noodles.

However, all is not plain sailing in this investment relationship. Following the Burmese government's decision to suspend the Letpadaung copper mine project until 2015 (the date for the next national elections), Chinese FDI contracted significantly. In an additional signal of combined commercial uncertainty and political displeasure in Beijing, April 2013 saw Sinopec sell its rights in an onshore Burma oil block it had held since 2004, to a Taiwanese company (WSJ 2014). Moreover, it is important to see Chinese FDI in context, relative 
to other investing countries. This is particularly the case in 2013 as projected full-year results suggest Chinese FDI to Burma was outstripped by that of South Korea, Singapore and Japan. On this estimate, China would slip to around tenth place. Between April and December 2013, Chinese FDI totalled approximately US\$18 million. With minimal additional investment, the full-year total was expected to be in the range of US $\$ 20$ million; about 20 per cent of the US $\$ 400$ million in fiscal year 2012 and under 1 per cent of the approximately US $\$ 8.2$ billion peak in fiscal year 2010. China, having been the leading source of FDI for fiscal years 2010-12, is anticipated to fall back to around tenth place in 2013 (Nikkei Asian Review 2014).

It is important to recognise that Sino-Burmese economic relations are not monolithic or homogenised in terms of the range of economic and political agencies involved. While the intergovernmental partnership sets the overall direction of bilateral relations and takes account of the international context, cooperation takes place through the multiple tiers of public administration in both countries, enterprises and business and cultural associations. One of the most obvious aspects of this is the relationship between China's Yunnan Province and Burma. Yunnan is the critical entry point for Burmese exports (legal and illegal) and for the strategically-vital oil and gas pipelines, as well as the long-established base of small- and mediumsized firms operating in Burma. Burma is Yunnan's largest trading partner and Yunnan-Burma trade accounts for 50 per cent of the total trade between China and Burma. In 2011, total Burmese trade with Yunnan reached US $\$ 2$ billion, up about 18 per cent compared to 2010. In 2012, Burma and Yunnan cross-border trade totalled US $\$ 1.7$ billion by October; a yearon-year rise of 2.2 per cent (Ectpa.org 2012). The trans-border bridgehead with Burma is important to Beijing leadership as well as the bridgeheads of Kunming and the other Yunnan cities. For the latter it is an important commercial link, while for Beijing it forms part of a wider policy picture; Yunnan and China's southwest is designated as a priority for economic development in Beijing's national economic plan and inter-state politics also enters into Beijing's perspective.

China's 'development' interest in Burma is primarily economic. This has two main aspects.
Firstly, Burma as supplier; the country's location offers an alternative transit route for Middle East oil supplied to China, Burmese natural gas reserves, hydroelectric potential and raw materials to help meet China's pressing energy needs. Secondly, Burma as a market for Chinese goods, given the anticipated growth of the postreform economy. Both aspects can, potentially, act as development gains for Burma - a part of the answer to the development challenge particularly if Burmese producers are able to enter into the value chain at a higher stage, based on a shift to a high-value economy. But they have also proven to be part of the problem. Chinese government and SOE corporate closeness to the Burmese military government and insensitivity to local community interests have generated increasing anti-Chinese sentiment unassuaged in the post-military rule years.

\section{(a) Resources}

China needs Burma's energy and raw materials which are vital to China's economic growth. The world's second largest economy was expected to grow by around 8 per cent in 2013. To sustain growth and meet rising consumer demands, it needs to import oil, gas and hydroelectric supplies as well as a range of raw materials from timber to strategic minerals. China's energy needs have grown considerably over the past 30 years of major economic growth and emerging consumer affluence, outstripping its domestic sources of supply, turning it into a net importer of oil and pushing it to import increasing amounts of oil and gas thereafter (EIA 2013). According to the EIA, China consumed 10.9 million barrels per day (bpd) but produced only 4.6 million bpd. China became the world's largest oil importer in September 2013 with demand exceeding supply by 6.3 million bpd (CBC News 2013).

It is a similar story with natural gas. Consumption in China went up from 25 billion cubic metres (bcm) in 2000 to over $100 \mathrm{bcm}$ in 2010 , and has been exceeding domestic production since 2007. China is actively seeking to cut its carbon emissions as well as diversify its energy base away from a 68 per cent dependency on coal. The Beijing government has prioritised natural gas as its best option - it aims to increase the share of gas in its energy profile from 4 per cent today to 10 per cent by 2020. However, while it seeks to double domestic gas production during this period, it also 
means that it will have to increase its imports significantly from $28.1 \mathrm{bcm}$ in 2011 to an estimated $77 \mathrm{bcm}$ a year by 2020 (Berdikeeva 2012).

China has a goal to produce at least 15 per cent of overall energy output by 2020 from renewable energy sources as the government aims to address environmental issues. Chinese companies invested US $\$ 65$ billion in renewable energy projects in 2012, 20 per cent higher than investments in 2011, and they plan to spend US $\$ 473$ billion on clean energy investments between 2011 and 2015 (EIA 2013).

\section{(b) Burma's market potential}

The UNDP argues that, by 2030, the East Asia and the Pacific region 'will be home to about two-thirds of the new global middle class, with billions of people becoming increasingly educated, socially engaged and internationally connected, though at significantly lower income levels than their counterparts in the middle class of the industrialised North' (UNDP 2013b). Against this regional backdrop, expectations of future growth in Burma are high in the wake of President Thein Sein's reforms. In addition to the projections of institutions such as the World Bank (Asian News Network 2013a) on Burma's potential GDP growth, some assessments, such as that of the McKinsey Global Institute, suggest that if the reform aims are realised, then Burma's GDP could quadruple in size over the next 20 years. This would see an increase to US $\$ 200$ billion, recording annual growth rates commensurate with those of China at 8 per cent and attracting US $\$ 100$ million FDI. The financial services and telecommunications sectors each offering a potential 23 per cent compound annual growth rate over the 2010-13 period (Bloomberg 2013).

Burma's new enterprise and ownership laws also open up the country's economy as an export platform to Europe and US markets as sanctions and embargoes are lifted and new trade and investment agreements come into force. This is already the case with South Korean firms moving into the Burmese textiles sector, some relocating from China, where rising labour costs are now becoming a factor.

\subsection{China's development assistance}

'Development' and international development assistance, as a defined area of Chinese foreign policy remains a work-in-process (Lum 2009). Overseas development is a relatively new factor for Beijing and a learning experience. The Chinese government published its first White Paper in 2011. Western or 'traditional' donor definitions and terminology, such as that of OECD-DAC, still do not translate readily into the current core concepts of China's political culture; for example, the concepts of economic or development aid is subsumed by the overarching concept of 'economic cooperation'. This term is deliberately broad, designed for the whole spectrum of economic and related noneconomic activity and includes, therefore, development aid, loans, technical assistance and state-sponsored investments.

With regard to Burma, China's main forms of economic cooperation are: grant aid, interestfree loans, and concessional loans, technical assistance, and debt relief. China provides assistance through concessional loans and grants in the key areas: agriculture, natural resource exploration, infrastructure, telecommunications, human resource management and industrial processing. In 2010 China pledged to provide Burma with US $\$ 4.2$ billion worth of interest-free loans over a 30 -year period to help fund hydropower projects, road and railway construction and IT infrastructure. China also provided Burma with technical assistance for agriculture development. Agriculture contributes 30 per cent of Burma's GDP with 61 per cent of the workforce in this sector. Beset by low crop production and farmer incomes, China collaborates with Burmese and Swiss organisations to provide training, technical advice, visits and exchanges and scientific cooperation to increase maize and rice production (CABI 2013).

Infrastructure provision is, of course, key. China is involved in all aspects of Burma's infrastructural capacity building including new airports, dams, bridges, rail and port facilities. China Communications Construction (CCG) has been constructing the US\$100 million airport in the new capital Naypyidaw, financed on reportedly generous terms by a China EximBank loan. In hydropower, the massive 7,110 MW Tasang Dam on the Salween River in Shan State, costing at least US $\$ 6$ billion, is majority owned and constructed by the SOE, China Gezhouba. Sinohydro, China's largest dam builder has built 
a number of hydropower stations in Burma, including the Yeywa hydropower station onstream in October 2011 (Myanmar Business Network 2011).

After three years of discussion and delay, the two governments agreed during President Thein Sein's visit to Beijing in late May 2011 to build an $810 \mathrm{~km}$ rail link between Yunnan and Burma's Indian Ocean port of Kyaukpyu via Muse. The China Development Bank provided a US\$763 million line of credit to the Burmese government during this visit. Under the rail agreement, China Railway would be responsible for building the line (phase one of five due for completion in 2014). While the Chinese communiqué justified the new link as strengthening bilateral economic ties that would 'boost the economic growth' of Burma, China's involvement is driven by its aim of strengthening its existing oil and gas 'hub' around Kyaukpyu in order to then parallel its new oil and gas pipelines stretching across to Yunnan which, in turn, Beijing is intent on liberating from its landlocked economic constraints to develop its western region as it lags behind the eastern coastal provinces. The project raises several human rights issues. Human Rights Watch's David Mathieson argues that 'The railroad will pass though parts of the Shan state that are still contested. But I'm more concerned about the security corridor attached to such projects, which have a past record for human rights abuses such as forced labour and land confiscation’ (Railpage 2011).

China's development approach is evident too in the controversial oil and gas pipeline construction. The project has been seeking to offset widespread opposition to the project and criticism of land expropriations, enforced dispossession, corruption and ecological disregard for rivers and forests. The project claims to have provided over 6,000 jobs for locals for the construction work, and involved over 220 Burmese firms with their employees being technically trained. They point to development aid projects undertaken along gas pipeline routes with US\$20 million donated for use in education, medical treatment, health and disaster relief, 45 schools and 24 clinics built to improve the teaching facilities for 19,000 students and medical facilities for 800,000 local people. The venture offered US\$10 million to repair a high voltage power grid line in Kyaukpyu, in which CNPC's donation accounted for US\$3 million. In the second half of 2012, when
Rakhine State experienced communal rioting, the project provided US $\$ 50,000$ cash aid and ten tonnes of rice. Moreover, they also donated US $\$ 50,000$ to earthquake victims in central Burma (China Daily 2013b). Similarly, the company behind the oil pipeline, SEAOP, committed itself to 'assist' Burma in implementing 25 development projects in its pipeline project areas, worth US\$1 million, in Rakhine State and the Magway region, providing 21 schools, two clinics and two kindergartens. The company claimed that, on completion, 1,320 villager patients, 105 preschool age children and 1,891 students would have benefited (GOV.cn 2012).

Illustrative of China's approach is the experience of one Chinese firm in the Burmese market, the China National Machinery Import and Export Corporation (CMC). The firm has followed a classic strategy of China's 'going out' policy of exporting from China, followed by in-country production backed by Chinese government development cooperation assistance. In the 1990 s, the company exported railway locomotives to Myanmar. In 2000, the company established LPG factories in Nyaungdon and Kyunchaung. In the 2004-08 period, CMC built a number of 'free aid' projects on behalf of the Chinese government. These included a hydroelectric assembly plant, Mandalay industrial training centre, and an electricity meter factory. In 2007, the firm also drew on Chinese government preferential loans for the Burmese government to provide 20,000 tonnes of steel rails for Burma's Ministry of Railways. In 2010 the company and the Ministry of Railways signed an MoU making use of Chinese government preferential loans to construct a new locomotive assembly plant and bus assembly plant (CMC 2014).

China also provided humanitarian assistance to Burma for purposes of disaster relief, drugs control, education, medical and health. For example, China promised US $\$ 4.3$ million in aid in addition to an initial US\$1 million in the aftermath of the 2008 Cyclone Nargis. In 2013 China pledged aid for the resettlement of Burma's homeless in western Rakhine State and victims of the earthquake in northern Burma in the form of 350 integrated housing units worth 30 million yuan and US $\$ 1$ million in cash for the resettlement of the victims (Chinese Embassy 2013). Technical assistance has also been extended to provide human resources training to about 
2,000 persons covering more than 20 sectors, and aid in the form of engineering machinery, medical instruments and teaching equipment. For example, China equipped Yangon University and Mandalay University with 1,500 computers (ibid.).

\subsection{Political relations}

The modern diplomatic relationship goes back to establishment of formal relations between Burma and the PRG in 1950. The diplomatic language of high-level meetings frequently refers to their shared paukphaw (fraternal) friendship. Certainly, there is a historical legacy at play here, China's long-standing political support for Burma during its long years of international exile, vetoing condemnatory resolutions in the UN Security Council being merely one obvious feature of such support. China's public position is that it supports Burma's decision to reform. China has had a series of high-level reciprocal visits to maintain dialogue with the Burmese government to ensure sustained and sustainable bilateral relations with the new reforming administration. China's consideration here is that the process of wholesale societal transformation being undertaken in a relatively short time schedule maintains the stability of Burma; a managed process of reform that will not create instability in an adjacent state and threaten the viability of Chinese assets and operations in the country. Beijing was widely held to have been slow off the mark in recognising and responding to the changes in Burma (Horton 2013). However accurate such impressions were, the Chinese government has moved to shore up its bilateral political ties with the new Burmese civilian leadership. Yet, an issue here relates to the very character of change taking place in Burma, with distinct resonances for China's own domestic and international reform trajectory. China's leaderships have always favoured and felt more comfortable working through government-togovernment relations. However, as in China, processes of economic and social change press political adjustments too. In China, the government has widely advocated the importance of people-to-people relations and the newly adopted reform strategy under President $\mathrm{Xi}$ Jinping has identified a more prominent role to be encouraged by civil society organisations. In Burma, political reform has opened up a new space for civil society and the media and also for new influence in the ethnic-oriented politics of
Burma's constitutive states. There is, therefore, recognition of a need to engage in a more committed and demonstrably genuine way to the emerging role of Burmese civil society - one deeply sceptical or opposed to China's presence (Berger 2013; Yang 2012).

The suspension of the Letpadaung copper mine by the Burmese government is more than a symbolic act. It is indicative of two elements of change. Firstly, as just noted above, the emergence of civil society and a rapid emergence of communities and societal groups willing and able to act on their new political freedoms - in this instance in protesting against those projects and their corporate sponsors that they argue have involved no consultation, recognition of villager interests and concerns, forced, uncompensated removals from their land, environmental threat or damage, and which are not going to contribute financially or in terms of employment, training or local traders. Late March 2014 saw thousands of Burmese people take part in a mass protest march seeking an outright termination of the project (The Irrawaddy 2014a). The Chinese approach has been criticised within China itself as well as in Burma. Corporate social responsibility, while understood in Chinese business and government, is still in its fledgling stage in China itself, and often not recognised as a legitimate corporate interest for Chinese firms 'going out' across the global economy. Chinese government spokespersons publicly stress that the government encourages social responsibility by Chinese firms in Burma, claiming that these Chinese companies have provided aid worth US $\$ 71$ million to Myanmar in education, health and natural disaster mitigation and created jobs for 15,000 people (Chinese Embassy 2013). Nonetheless, there are signs of change evident in the corporate sector. In response to the Letpadaung mine suspension, the Chinese developer, Wanbao Mining Ltd, a subsidiary of state-owned Chinese arms manufacturer China North Industries Corporation, signed a revised contract in October 2013, increasing its investment from US $\$ 600$ million to US $\$ 997$ million, cutting its share of profits from 49 per cent to 30 per cent (Burma government receiving 51 per cent, up from 4 per cent under the original contract). It also promised more than US $\$ 1$ million a year in social investments in villages around the mining site. The company will also channel 2 per cent of profits towards corporate social responsibility projects once the 
mine is in operation. Yet, illustrative of the legacy of military rule, Wanbao's original partner, the military-backed Union of Myanmar Economic Holdings, will still have a stake in the profits, albeit with its share drastically cut from 45 per cent to 19 per cent, once the mine is back to producing copper (WSJ 2014).

Secondly, Letpadaung is also highly instructive for the Chinese government in underlining a change in attitude to development assistance and infrastructural development project funding and management towards China. The Burmese government turned down a US $\$ 2$ billion Chinese government loan to construct a proposed highway linking the planned Kyaukpyu industrial zone on Burma's west coast, with Ruili in southwest China, preferring instead that the roadway be developed under a build-operate-transfer (BOT) scheme in which the investors usually recoup their outlay through payments by users, accrued while investors operate the project after it opens. Burma's Deputy Construction Minister Win Myint stated that: 'If they want to construct this highway they can make a joint venture with a Myanmar company. If they want to build this road from the China side, they are welcome'. The proposed roadway will link Kyaukpyu, site of a proposed 1,000-acre Special Economic Zone (SEZ) and deep-sea port on Burma's Bay of Bengal coast, to Ruili, a Chinese town just across the border from Muse in Shan State. Burma's Railway Ministry is currently also reviewing a Chinese proposal to build an almost $900 \mathrm{~km}$ rail line from Kyaukpyu to Kunming; which is likely also to be built and operated under a BOT scheme (The Irrawaddy 2014b).

If there are national Burmese factors here for China, there are also regional political considerations as well. Relations with Burma are contextualised by China's relationship with ASEAN. China's leadership has recommitted itself to working closely with Southeast Asia and with ASEAN as it moves to the threshold of the ASEAN Regional Community and closer integration between its members (Hendrikson 2013). Burma is politically important to China for added potential regional influence. Burma's political standing has risen since 2011; 2014 sees Burma's tenure of the Chair of ASEAN and will host the organisation's Summit. ASEAN itself is bringing in its own ASEAN Economic Community in 2015 and overlaps with China's ASEAN-China Free Trade Area.
For China, a close relationship with Burma also carries a political message to both the global North and South, one now familiar in Africa and Latin America. Beijing's message is that, as a former colonialised country and still a developing country, China understands and stands alongside the developing world. This rhetoric dovetails nicely for China's current political worldview. Developing world solidarity overlaps with China's 'Five Principles of Coexistence' and the 'Bandung Spirit'. These are woven into deeplyrooted anti-imperialism narratives in Chinese public political discourse, the 'Five Principles' being cited as the opening point of the 2011 China-Burma Strategic Partnership agreement.

\subsection{Security relations}

The central Chinese security interests in Burma are that of border security and protection of Chinese strategic oil and gas supply pipelines.

\section{(a) Border security}

Border security has featured prominently in the series of China-Burma high-level leadership visits since the election of the civilian government, as well as in the Strategic Partnership agreement. Instability and violence in adjacent Kachin State between the Burmese army and the Kachin Independence Army (KIA), the armed wing of the KIO, has reverberations in China's neighbouring Yunnan Province; four rockets have exploded in the border areas north of Ruili since December 2012. Beijing's concern is over the potential for a 'spillover' of this ethnic conflict into Yunnan, itself a multi-ethnic community (The Irrawaddy 2012). Yunnan has seen an influx of displaced persons, an estimated 60,000 at the height of the conflict. But the border security issue is broader in scope, including illegal trans-border trade from drugs, logging (Global Witness 2009; Asian News Network 2013b) and human trafficking.

There is also a sizable Chinese-Burmese community, estimated at around 1.6 million and China has taken a closer interest in the wellbeing of Chinese communities in Southeast Asia, including Burma, following attacks on ethnic Chinese in the region. This Chinese community in Burma is centuries old (Vandenbosch 1947). Inflows of Chinese immigrants came in the period of British colonialism and in the wake of the Communist victory in the Chinese civil war in 1949. 
Resentment at the economic and cultural impact of this ethnic group has simmered, boiling over in the 1967 Yangon riots and the expulsion of Chinese communities from Burma, and generating hostility in both countries and in 2008, open violence against Burma's Chinese community.

\section{(b) Strategic security}

Burma is being portrayed as a new 'battleground' in a Sino-US 'proxy war'. Burma's strategic significance has skyrocketed in the past two years. It is a vital Chinese strategic interest for a number of reasons. It is at a geo-strategic crossroads upwards to China, northwest to India and eastwards to Thailand and Southeast Asia. Neo-containment or not, Burma is strategically sensitive.

For example, China imports growing amounts of oil and gas from the Middle East. Burma's geography offers China an important friend on the Andaman Sea by offering means of patrolling more extensively and for longer China's critical supply routes from the Gulf through the Indian Ocean and Straits of Malacca with some risk of piracy. To counter supply risk, China has developed US $\$ 2.5$ billion worth of new pipelines taking oil and natural gas from Burma itself and as a transit from the Middle East. Cutting a swathe across Burma, from its deep-water port of Kyaukpyu in the Bay of Bengal in the west to Muse in the east, these are key strategic assets for China and at almost $800 \mathrm{~km}$, are long and exposed. This generates revenue for Burma. But whose Burma? Who benefits from such revenues (Linn 2012)? Given the duration of the military rule, it is a short period of time and requisite of a massive concerted and politically-charged process since 2011 to enact root-and-branch reform across the whole system. Nonetheless, the critical issue remains the structural power of the Burmese armed forces (Tatmadaw) in the Burmese market, alleged corporate cronyism and its long-established relations with segments of the Chinese military-political-economic elite.

\section{The gas taps turned on in 2013 (People's Daily} Online 2013), but the projects are mired in controversy and opposition. In addition, Burma's Rakhine State, where the pipeline begins, saw inter-communal violence between Buddhists and Muslims in June and October 2012 which left hundreds dead and injured. Oil and gas sales, sales of legally (and illegally) logged timber as well as narcotics from Burma's poppy-fields are all, allegedly, tied up with the Burmese military, its corporate grip on the country and its arms purchases.

But the competitive dimension with Japan is evident in the latter's ODA provision for Burma's port modernisation announced in December 2013 with the construction of two new general cargo wharves at the Myanmar International Terminals Thilawa (MITT) port paid for with a US\$205 million Japanese ODA loan (consult-myanmar.com 2013).

\section{Conclusions}

International politics are rarely, if ever, 'zerosum'. China's interests in Burma, including a national interest in supporting Burma's economic and socio-political development, are clear. China's development assistance is framed in a wider concept and practice of 'economic cooperation'. This is delivering (swiftly) muchneeded major infrastructure to Burma.

Burma and China have symbiotic interests and long-standing relations that mean that, quite apart from the imperatives of geography, their relationship will be relatively close. But the relationship has been significantly one-sided in favour of China and Burma is now seeking to balance its China interests with those of a newly engaged international community and to work with China on a more equitable basis, for example, through BOT agreements and more joint ventures.

\section{This analysis has shown Burma's immense} potential and sought to demonstrate China's continuing 'economic cooperation' approach to Burmese development. What more could or should China be doing to more readily provide effective assistance for Burma's development? The Chinese central government and Chinese enterprises need to adjust to Burma's new economic, political and social condition in practice rather than with mere diplomatic rhetoric. A failure to do so has contributed to an exacerbation of the long-standing popular latent antipathy towards the Chinese state and enterprise presence in China. Such an adjustment could include:

A continued incorporation of the international conception, accepted principles and practices 
of 'development assistance' into China's 'economic cooperation' and 'comprehensive cooperation partnership' with Burma. China should broaden its development profile beyond narrow national economic self-interest - best characterised perhaps as an 'enlightened self-interest';

- To do this there needs to be a greater commitment to corporate social responsibility by more Chinese firms in Burma which would begin the process of ameliorating anti-Chinese sentiment. Faced with growing and widening popular protests against many of China's Burmese 'mega-projects' and important signals of Chinese government disquiet in the Chinese official press, Chinese SOEs involved have poured money into social and economic developments in their project areas. However, given the damage already done to the image of China in Burma, throwing money at the problem is proving insufficient to quell local discontent which views this as a cynical tactic rather than a demonstrable change in corporate

\section{References}

All urls accessed 11 April 2014.

ADB (2013) Asian Development Bank and Myanmar: Fact Sheet 2013, Philippines: Asian Development Bank, www.adb.org/sites/default/files/pub/ 2013/MYA.pdf

Amnesty International (2013) Annual Report on Myanmar 2013, www.amnesty.org/en/region/ myanmar/report-2013

Asia Tribune (2012) 'Burma and the International Development Aid and FDI', 2 June, www.asiantribune.com/news/2012/06/01/burmaand-international-development-aid-and-fdi

Asian News Network (2013a) World Bank Sees Record Growth in 2014 for Myanmar, But Poor Remain at Risk, 11 July, www.asianews.it/news-en/WorldBank-sees-record-growth-in-2014-forMyanmar,-but-poor-remain-at-risk-29483.html Asian News Network (2013b) Chinese Illegal Logging, Smuggling Worsen in Myanmar, 3 May, www.asianewsnet.net/Chinese-illegal-loggingsmuggling-worsen-in-Myanma-46237.html

Australian Government (2014) Burma Country Brief, Canberra: Department of Foreign Affairs and Trade, www.dfat.gov.au/geo/burma/ burma_brief.html

BBG News (2013) Burma gets Asian Development Bank and World Bank Loans, 28 January, www.bbc.co.uk/news/business-21226344 culture and practice. For this to change, such corporate social responsibility (CSR) initiatives need to be backed by additional measures by the Chinese government, for example, becoming a supporting country to the Extractive Industries Transparency Initiative (EITI) and a more robust promotion of CSR to Chinese business in association with Chinese business councils, and building on its existing public relations campaigns with local Burmese communities (Sun 2012);

- Chinese firms in Burma committing to greater transparency and accountability, adopting an inclusive and equitable approach to project contracting and development and adhering to new Burmese regulations for social and environmental impact assessment.

These are achievable initiatives. A sustainably developing Burma is in China's own national interest and can deepen the developmental dimension of paukphaw (fraternal) friendship in the coming years.

Becker, Jo (2013) 'In Myanmar the Underground Trade in Boy Soldiers Continues', The Nation, 2 July, www.hrw.org/news/2013/07/02/ myanmar-underground-trade-boy-soldierscontinues

Berdikeeva, Saltanat (2012) China Turns to Natural Gas to Fuel their Economic Growth, oilprice.com, 19 June, http://oilprice.com/Energy/NaturalGas/China-Turn-to-Natural-Gas-to-Fuel-theirEconomic-Growth.html

Berger, Bernt (2013) 'China's Troubled Myanmar Policy', The Diplomat, 23 August, http://thediplomat.com/2013/08/chinastroubled-myanmar-policy/1/

Bloomberg (2013) Myanmar may Attract $\$ 100$ Billion in FDI by 2030, McKinsey Says, 29 May, www.bloomberg.com/news/2013-05-29/ myanmar-may-attract-100-billion-in-fdi-by2030-mckinsey-says.html

CABI (2013) CABI and China Boost Agricultural Development in Myanmar, www.cabi.org/ membership/news/cabi-and-china-boostagricultural-development-in-myanmar/

GBC News (2013) China Overtakes US to Become World's Biggest Oil Importer, 10 October, www.cbc.ca/news/business/china-overtakes-us-to-become-world-s-biggest-oil-importer1.1958511 
China Daily (2013a) 'China, Myanmar Deepen Military Ties', 17 October,

http://usa.chinadaily.com.cn/world/2013-10/ 17/content 17038081.htm

China Daily (2013b) 'Sino-Myanmar Trade

Provides Huge Investment Chances',

16 January, www.chinadaily.com.cn/hkedition/

2013-01/16/content_16123034.htm

Chinese Embassy [in Myanmar] (2013) China

Provides Aid for Resettlement of Myanmar Homeless, 1 January, http://mm.china-embassy.org/eng/ sgxw/t 1002211.htm

CMC (2014) Homepage, www.cmc.com.cn/en/ Content.aspx?PartNodeId $=369$

Consult-myanmar.com (2014a) Companies Act Update Coming in May, Say Experts, 13 January, http://consult-myanmar.com/2014/01/13/ companies-act-update-coming-in-may-sayexperts/

Consult-myanmar.com (2014b) Foreign and Domestic Investors Play by Same Rules: DICA, 20 January, http://consult-myanmar.com/?s= Foreign + and +Domestic + Investors + Play + by + Same + Rules $\% 3 \mathrm{~A}+$ DICA

Consult-myanmar.com (2013) Myanmar to Construct 2 Cargo Wharves at Thilawa with ODA Loan, 2 December, http://consult-myanmar.com/ ?s $=$ Myanmar + to + Construct $+2+$ Cargo + Wharves + at + Thilawa + with + ODA+Loan

Ectpa.org (2012) Myanmar-Yunnan Trade Tops $\$ 1.7$ Billion, Kunming: Southeast Asia and South Asia Infoport, 17 December, http://english.ectpa.org/article/Information/ LatestNews/201212/20121200023618.shtml

EIA (2013) US Energy Information Agency Country Report-China: Analysis, Washington DC, www.eia.gov/countries/cab.cfm?fips $=\mathrm{CH}$

Global Witness (2009) A Disharmonious Trade: China and the Continued Destruction of Burma's Northern Frontier Forests, A Global Witness Review 2006-09, www.globalwitness.org/sites/ default/files/import/a_disharmonious_trade_ pages_1_15.pdf

GOV.cn (2012) Chinese Oil Company to Aid 25

Socio-economic Development Projects, 14 January, http://english.gov.cn/chinatoday/2012-01/14/ content_2044164.htm

Hendrikson, Lars (2013) How China is Courting Southeast Asia, 4 November, http://moneyweek.com/china-courtingsoutheast-asia/

Horton, Chris (2013) 'China Didn't See this Coming', The Atlantic, 15 March, www.theatlantic.com/china/archive/2013/03/ china-didnt-see-this-coming/274042/

IndexMundi (2012) Myanmar-Net Official

Development Assistance Received, www.indexmundi.com/facts/myanmar/netofficial-development-assistance-received

Linn, Zin (2012) Analysis: Burma, International Development Aid and FDI, 1 June, asiancorrespondent.com

Lum, T. (2009) China's Foreign Aid Activities in Africa, Latin America, and Southeast Asia, Federation of American Scientists, www.fas.org/sgp/crs/row/R40361.pdf

MPED and Ministry of Health (2011) Myanmar Multiple Indicator Cluster Survey (MICS) 2009-2010 Final Report, Nay Pyi Taw, Myanmar: Ministry of National Planning and Economic Development (MPED) and Ministry of Health Myanmar Business Network (2011) Asian Development Bank (ADB) and Major Chinese Banks to Support Investment Projects in Myanmar, 21 April, www.myanmar-business.org/2011/04/ asian-development-bank-adb-together.html

Nikkei Asian Review (2014) Myanmar Sheds Dependence on Chinese Investment, 27 March, http://asia.nikkei.com/Business/Trends/ Myanmar-sheds-dependence-on-Chineseinvestment

Oxfam (2014) Riding the Wave of Reform: Fasttracking Myanmar's Future with Good-quality Aid, Oxfam Briefing Paper, www.oxfam.org/sites/ www.oxfam.org/files/bp-riding-wave-reformmyanmar-aid-210114-summ-en.pdf

People's Daily Online (2013) 'Myanmar-China Gas Pipeline Starts to Deliver Gas to China', 29 July, http://english.peopledaily.com.cn/ 90778/8343775.html

Railpage (2011) Blogspot, www.railpage.com.au/ f-t 11353745.htm

SDC (2013) The Swiss Cooperation Strategy Myanmar 2013-2017, Bern: Swiss Agency for Development and Cooperation (SDC), www.swiss-cooperation.admin.ch/laos/en/ Home/ressources/resource_en_224776.pdf

Sun, Yun (2012) 'China and the Changing Myanmar', Journal of Current Southeast Asian Affairs 4: 51-77

Taylor, Robert (ed.) (2001) Burma: Political Economy under Military Rule, London: Hurst

The Irrawaddy (2014a) 'Thousands March for Termination of Burma's Myitsone Dam', 21 March, www.irrawaddy.org/z_environment/ thousands-march-termination-burmasmyitsone-dam.html

The Irrawaddy (2014b) 'After Snubbing Loan, 
Burma Awaits China's Response on Road Link', 18 March, www.irrawaddy.org/business/ snubbing-loan-burma-awaits-chinas-responseroad-link.html

The Irrawaddy (2012) 'China Urges Burma to Secure Border, Infrastructure Projects', 24 February, www2.irrawaddy.org/ article.php?art_id=23092

Thin, Myint (2013) 'The Prospects for Burma's Economic Development', The Irrawaddy, 6 February, www.irrawaddy.org/commentary/ across_irrawaddy/the-prospects-for-burmaseconomic-development.html

Trading Economics (2014) Myanmar Balance of Trade, 2 April, www.tradingeconomics.com/ myanmar/balance-of-trade

TI (Transparency International) (2013) Country Profile: Myanmar, www.transparency.org/ country\#MMR

UNDP (2013a) United Nations Development Programme in Myanmar, Washington DC: UNDP, www.mm.undp.org/myanmar/en/home.html UNDP (2013b) The Rise of the South: Human Progress in a Diverse World, Human Development Report, Washington DG: UNDP, http://hdr.undp.org/en/2013-report
US Government, Dept. of State (2013) US Relations with Burma, Bureau of East Asian and Pacific Affairs, Fact Sheet, 13 August, www.state.gov/r/pa/ei/bgn/35910.htm

Vandenbosch, Amry (1947) 'The Chinese in Southeast Asia', The Journal of Politics 9.1: 80-95, www.jstor.org/stable/2125860

WSJ [Wall Street Journal] (2014) 'Party Time in Myanmar, for Those with Invitations', 27 March, http://blogs.wsj.com/searealtime/ 2014/03/27/party-time-for-energy-firms-inmyanmar-for-those-with-invitations/

WSJ [Wall Street Journal] (2013) 'Chinese Company Launches Charm Offensive in Myanmar', 9 October, http://online.wsj.com/ news/articles/SB1000142405270230452070457 9125083505961324

World Bank (2014) Myanmar Overview, Yangon/ Washington DC: World Bank Group, www.worldbank.org/en/country/myanmar/ overview

Yang, Meng (2012) 'Chinese Power, Burmese Politics', China Dialogue, 2 April, www.china dialogue.net/article/show/single/en/4852 